\title{
Indikator Ekonomi Subsektor Perikanan Tangkap Indonesia di Masa Pandemi Covid-19 Tahun 2020
}

\author{
(The Economic Indicators of Indonesian Fisheries Subsector during The Covid-19 Pandemic, 2020) \\ Miko Novri Amandra ${ }^{1 *}$, Bayu Rhamadani Wicaksono ${ }^{2}$, Evita Choiriyah'², Penny Wulandari² \\ ${ }^{1}$ Kementerian Kelautan dan Perikanan, IPB University \\ ${ }^{2}$ Badan Pusat Statistik RI \\ Jl. Medan Merdeka Timur No. 16 Jakarta pusat \\ E-mail: miko.amandra@kkp.go.id
}

\begin{abstract}
ABSTRAK
Terhambatnya kegiatan perekonomian di masa pandemi Covid-19 menyebabkan subsektor perikanan tangkap Indonesia yang masih didominasi oleh nelayan kecil rentan terhadap kemiskinan. Kajian khusus dibutuhkan untuk melihat daya beli nelayan melalui indeks nilai tukar nelayan (NTN). Fluktuasi NTN dapat dipengaruhi oleh beberapa faktor, beberapa diantaranya adalah indeks konsumsi rumah tangga (IKRT) nelayan, nilai ekspor perikanan tangkap, dan jumlah penambahan kasus aktif Covid-19. Penelitian ini bertujuan untuk melihat pengaruh jangka pendek dan jangka panjang faktor-faktor tersebut terhadap NTN Indonesia di masa pandemi Covid-19 serta kecepatan konvergensi NTN provinsi. Analisis yang digunakan adalah regresi data panel dinamis pada data bulanan 2020 dari 34 provinsi seluruh Indonesia. Hasil penelitian ini menunjukkan nilai ekspor perikanan tangkap berpengaruh jangka pendek terhadap NTN, sedangkan penambahan jumlah kasus aktif Covid-19 berpengaruh jangka pendek dan panjang terhadap NTN. Kesenjangan NTN antar provinsi berkurang 17,21 persen per bulan dan mencapai setengahnya dari kondisi awal (half time convergence) dalam waktu 4 bulan.
\end{abstract}

Kata kunci: Covid-19, NTN, data panel dinamis

\begin{abstract}
The disruption of economic activities during the Covid-19 pandemic has caused the fisheries subsector in Indonesia, which is dominated by small scale fishers, to be vulnerable to poverty. A particular study is needed to measure the purchasing power of fishers through the fisher's term of trade (NTN). The fluctuations of NTN can be affected by several factors, including the household consumption index (IKRT) of fishers, the value of fisheries exports, and the increasing number of Covid-19 active cases. This study aims to measure the short-term and long-term effects of those factors on NTN during the Covid-19 pandemic and the speed of convergence of province's NTN. The analysis used is dynamic panel data regression on monthly data 2020 from 34 provinces in Indonesia. This study shows that the value of fisheries exports has a short-term effect on NTN, while the increasing number of Covid-19 active cases has short-term and long-term effects on NTN. The NTN gaps between provinces is reduced by 17.21 percent per month and reaches half time convergence within 4 months.
\end{abstract}

Keywords: Covid-19, fisher's term of trade, dynamic panel data

\section{PENDAHULUAN}

Pandemi coronavirus disease of 2019 (Covid-19) tercatat telah memasuki Indonesia sejak bulan Maret 2020. Upaya Indonesia dalam menekan penyebaran Covid-19 telah menghambat kegiatan perekonomian dan kesejahteraan sosial masyarakat (UNICEF et al., 2021). Terhambatnya perekonomian Indonesia ditandai dengan laju pertumbuhan negatif produk domestik bruto (PDB) tahun 2020 yaitu $-2,07$ persen (y-on-y). Subsektor perikanan sebagai salah satu komponen penyusun PDB juga mengalami laju pertumbuhan negatif pada triwulan II dan III tahun 2020 yaitu $-0,63$ persen dan -1,03 persen (y-on-y). Pada tahun 2020, PDB subsektor perikanan hanya melaju positif di angka 0,73 persen, padahal tahun sebelumnya mampu melaju positif hingga 5,73 persen (y-on-y) (BPS, 2021a).

Subsektor perikanan terbagi ke dalam dua kegiatan utama yaitu perikanan tangkap dan perikanan budidaya. Adapun usaha perikanan tangkap Indonesia masih didominasi oleh nelayan kecil (Sariagri, 2020). Nelayan kecil sangat rentan terhadap guncangan kemiskinan dibandingkan dengan subsektor pertanian lainnya (Anna, 2019). Kajian khusus dibutuhkan untuk melihat daya beli nelayan di Indonesia.

Salah satu pendekatan untuk mengukur daya beli nelayan adalah melalui indeks nilai tukar nelayan (NTN) (Rachmat, 2013). Meningkatnya daya beli nelayan diharapkan berimbas kepada perbaikan kesejahteraan 
nelayan untuk bertahan di masa pandemi Covid-19. Gambar 1 menunjukkan pada awal masa pandemi Covid19 NTN bulanan Indonesia turun dari 100,05 menjadi 98,49. Namun NTN mulai naik hingga kembali di atas angka 100 pada bulan Juli hingga Desember 2020. Badan Pusat Statistik (BPS) menyusun NTN 2020 menggunakan tahun dasar 2018 (BPS, 2021c).

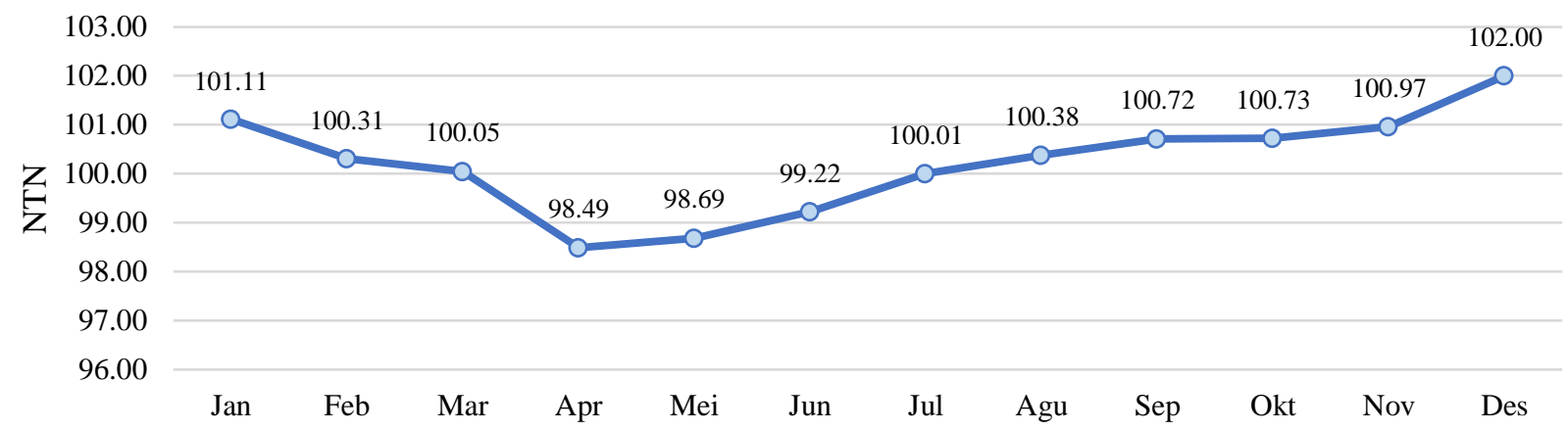

Sumber:Badan Pusat Statistik, 2021

Gambar 1. Nilai Tukar Nelayan (NTN) Indonesia, 2020

Peningkatan dan penurunan NTN dapat dipengaruhi oleh beberapa faktor, antara lain tingkat inflasi di perdesaan yang ditentukan melalui indeks konsumsi rumah tangga (IKRT) (Ramadhanu, 2021), nilai ekspor perikanan tangkap (Ratnasari dan Rijanta, 2020), dan fenomena lingkungan seperti yang terjadi saat ini yakni pandemi Covid-19 (Darwis et al., 2020). Penelitian ini bertujuan untuk melihat pengaruh jangka pendek dan jangka panjang IKRT nelayan, nilai ekspor perikanan tangkap, dan jumlah penambahan kasus aktif Covid-19 terhadap NTN Indonesia di masa pandemi Covid-19 tahun 2020. Analisis yang dilakukan menggunakan regresi data panel dinamis pada data bulanan tahun 2020 dari 34 provinsi di seluruh Indonesia. Hasil penelitian ini diharapkan dapat memberikan kontribusi rekomendasi kebijakan untuk mendukung percepatan pemulihan ekonomi nelayan Indonesia.

Berdasarkan pengetahuan penulis, penelitian terdahulu hanya meneliti pengaruh IKRT, nilai ekspor perikanan tangkap, maupun pandemi Covid-19 pada level regional (desa, kabupaten, atau provinsi), misalnya penelitian yang dilakukan oleh Kholis et al. (2020). Selain itu, penelitian terdahulu tidak melihat pengaruh jangka pendek dan jangka panjang yang menggabungkan unsur kerat lintang (cross section) dan deret waktu (time series). Hipotesis penelitian ini adalah IKRT nelayan dan jumlah penambahan kasus aktif Covid-19 memiliki pengaruh negatif terhadap NTN di Indonesia. Sedangkan nilai ekspor perikanan tangkap memiliki pengaruh positif terhadap NTN di Indonesia.

\section{METODE}

\section{Data dan Sumber Data}

Data yang digunakan dalam penelitian ini adalah data panel pada 34 provinsi di Indonesia periode JanuariDesember 2020. Data NTN menjadi peubah tak bebas, sedangkan data IKRT nelayan, nilai ekspor perikanan tangkap, dan jumlah penambahan kasus aktif Covid-19 menjadi peubah bebas. Data NTN dan IKRT nelayan yang digunakan merupakan data bulanan dengan tahun dasar 2018 yang diperoleh dari BPS (BPS, 2021c). Data nilai ekspor perikanan tangkap per bulan diperoleh dari BPS (BPS, 2021d). Data penambahan jumlah kasus aktif Covid-19 per bulan diperoleh dari Komite Penanganan Covid-19 Pemulihan Ekonomi Nasional (KPCPEN, 2021). Definisi operasional dari setiap peubah dalam penelitian ini sebagai berikut:

Peubah Tak Bebas

Nilai Tukar Nelayan (NTN)

: Daya beli nelayan di masing-masing provinsi per bulan dengan tahun dasar 2018

$\underline{\text { Peubah Bebas }}$

- Indeks Konsumsi Rumah Tangga : Indeks konsumsi rumah tangga (IKRT) nelayan di masing-masing nelayan (IKRT) provinsi per bulan dengan tahun dasar 2018

- Ekspor Perikanan Tangkap (EKS) : Nilai ekspor komoditas perikanan tangkap di masing-masing provinsi per bulan (US\$)

- Covid-19 (COV)

: Jumlah penambahan kasus aktif Covid-19 di masing-masing provinsi per bulan (Jiwa) 


\section{Metode Penelitian}

Analisis data yang digunakan adalah analisis data panel dinamis yang diolah dengan software RStudio. Analisis data panel dinamis digunakan untuk mengetahui peubah bebas yang berpengaruh terhadap peubah tak bebas yaitu NTN sebagai indikator daya beli nelayan dalam jangka pendek dan jangka panjang serta kecepatan konvergensi dari NTN provinsi di Indonesia menuju ke suatu nilai tertentu. Regresi data panel dinamis merupakan metode regresi yang menambahkan lag peubah tak bebas sebagai peubah bebas (Baltagi, 2008). Persamaan model dinamis didefinisikan sebagai berikut:

$$
y_{i t}=\alpha+\gamma y_{i t-1}+X_{i t} \beta+e_{i t}
$$

dengan:

$y_{i t} \quad=$ amatan pada peubah tak bebas individu ke- $i$ pada waktu ke- $t$

$\alpha \quad=$ intersep

$\gamma \quad=$ koefisien lag peubah tak bebas

$y_{i t-1}=$ amatan pada peubah tak bebas individu ke- $i$ pada waktu ke- $(t-1)$

$X_{i t} \quad=$ matriks amatan pada peubah bebas berukuran $l \times k$

$\beta \quad=$ vektor koefisien peubah bebas berukuran $k \times 1$

$e_{i t}=$ error regresi panel untuk unit individu ke- $i$ pada waktu ke- $t$

Pendugaan parameter pada model panel dinamis menggunakan First Difference Generalized Method of Moment (FDGMM) yang akan menghasilkan pendugaan konsisten, valid dan tidak bias. Pengujian konsistensi menggunakan Uji Arellano-Bond dan pengujian validitas instrumen menggunakan Uji Sargan. Sedangkan model dapat dikatakan tidak bias jika posisi nilai parameter lag peubah tak bebas menggunakan pendugaan parameter FDGMM terletak di antara nilai parameter lag peubah tak bebas menggunakan pendugaan pool least square dan fixed effect model (Arellano dan Bond, 1991).

Pada model data panel dinamis pengaruh jangka pendek dapat dilihat dari vektor koefisien peubah bebas $(\beta)$. Pengaruh jangka panjang peubah tak bebas dihitung dengan rumus sebagai berikut:

$$
C L R_{j}=\frac{\beta_{j}}{1-\gamma} \text { dengan } j=1,2, \ldots, k \text {. }
$$

dengan:

$C L R_{j}=$ koefisien jangka panjang peubah bebas ke- $j$

$\beta_{j} \quad=$ koefisien peubah bebas ke- $j$

$\gamma \quad=$ koefisien lag peubah tak bebas

Kecepatan konvergensi (speed of corvergence) menunjukkan kecepatan nilai amatan peubah bebas antara individu menuju ke suatu nilai tertentu (steady state). Kecepatan konvergensi dihitung dengan menggunakan rumus kecepatan konvergensi $(\lambda)=-\ln (\gamma)$. Waktu yang diperlukan untuk menutup setengah kesenjangan (half time convergence) dapat dicari dengan menggunakan rumus $\ln (2) / \lambda$ (Yuniasih et al., 2013).

\section{HASIL DAN PEMBAHASAN}

\section{Deskripsi Data}

Tabel 1 menunjukkan rata-rata NTN nasional periode Januari-Desember 2020 sebesar 100,27 yang menunjukkan bahwa daya beli nelayan relatif rendah. Rata-rata IKRT nelayan di level nasional periode Januari-Desember 2020 sebesar 105,99. Angka ini menunjukkan tingkat konsumsi rumah tangga nelayan masih relatif rendah pada masa pandemi.

Tabel 1. Statistik deskriptif peubah bebas dan peubah tak bebas

\begin{tabular}{crrrr}
\hline Peubah & Rata-rata & Simpangan Baku & Terendah & Tertinggi \\
\hline NTN & 100,27 & 4,22 & 90,23 & 113,7 \\
IKRT & 105,99 & 1,16 & 103,16 & 109,7 \\
EKS (US\$) & 8.123 .781 & 20.000 .000 & 0 & 114.000 .000 \\
COV (Jiwa) & 1.824 & 4.819 & 0 & 46.873 \\
\hline
\end{tabular}

Sumber: BPS, KPCPEN, 2021 (diolah)

Gambar 2 menunjukkan fluktuasi nilai ekspor perikanan tangkap periode Januari-Desember 2020. Fluktuasi nilai ekspor perikanan tangkap selama pandemi antar bulan menunjukkan kenaikan dan penurunan yang tidak signifikan. Pada awal masa pandemi bulan Maret-Mei nilai ekspor perikanan tangkap terus 
menunjukkan penurunan tajam dari 280,09 juta US\$ menjadi 205,20 juta US\$ dan terendah selama tahun 2020. Kemudian mulai bulan Juni-Oktober, nilai ekspor perikanan tangkap terus menunjukkan kenaikan hingga mencapai titik tertinggi yaitu pada bulan Oktober (347,32 juta US\$).

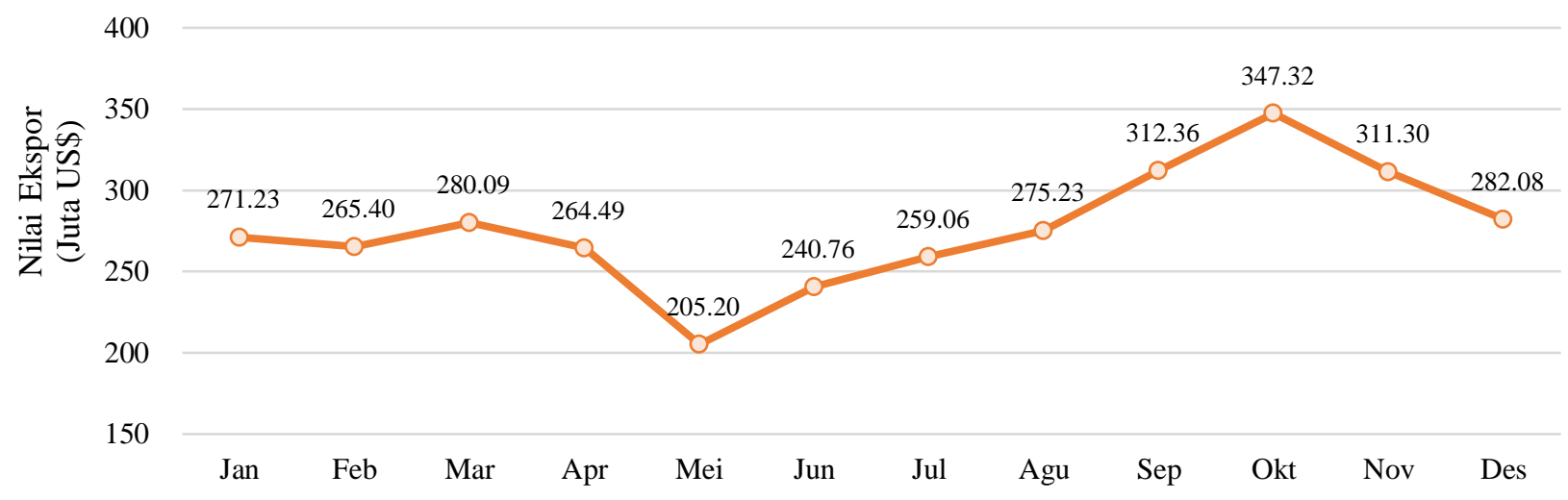

Sumber: BPS, 2021 (diolah)

Gambar 2. Nilai Ekspor Perikanan Tangkap Indonesia, 2020

Jumlah penambahan kasus aktif Covid-19 bulan Maret-Desember 2020 mencapai 744.022 jiwa. Provinsi dengan jumlah penambahan kasus aktif tertinggi adalah Provinsi DKI Jakarta dengan jumlah penambahan kasus sebesar 183.698 jiwa. Provinsi DKI, Jawa Timur, Jawa Barat, Jawa Tengah, dan Sulawesi Selatan merupakan lima provinsi dengan tren kenaikan jumlah kasus aktif Covid-19 yang cukup signifikan sejak pertengahan hingga akhir tahun 2020 (Lihat Gambar 3). Kenaikan jumlah penambahan kasus aktif Covid-19 di beberapa provinsi tidak memberikan dampak negatif terhadap pertumbuhan PDB perikanan dan daya beli nelayan pada level nasional (BPS, 2021b).

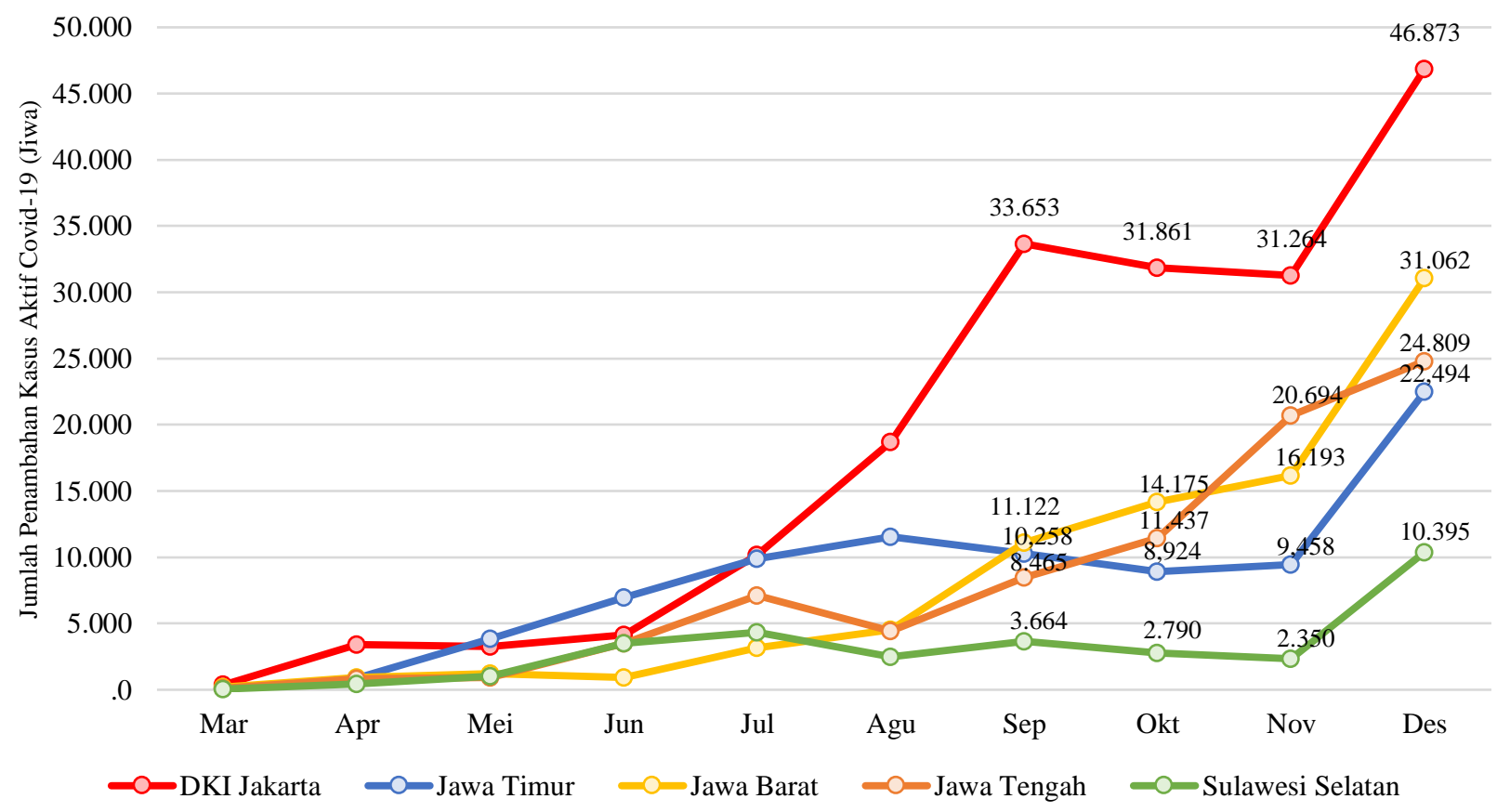

Sumber: KPCPEN, 2021 (diolah)

Gambar 3. Provinsi dengan Penambahan Kasus Aktif Covid-19 Tertinggi, 2020

\section{Analisis Data Panel Dinamis}

Pengujian spesifikasi model panel dinamis melalui pendugaan FDGMM Arellano-Bond dilakukan dengan cara melihat ketakbiasan, validitas instrumen, dan kekonsistenan (Arellano dan Bond, 1991). Berdasarkan Tabel 2 koefisien peubah lag NTN bernilai 0,842 (koefisien lag NTN < 1) dan terletak antara nilai 0,835 dan 0,989. Nilai 0,835 merupakan hasil pendugaan menggunakan dynamic fixed effect model (FEM) sedangkan nilai 0,989 merupakan hasil pendugaan menggunakan dynamic pool least square (PLS) model. Hal ini menunjukkan bahwa model pendugaan menggunakan FDGMM Arellano-Bond tidak bias. 
Tabel 2. Hasil uji spesifikasi model

\begin{tabular}{crc}
\hline Kriteria & Nilai Kriteria & p-value \\
\hline Koefisien Lag Dynamic FEM & 0,835 & 0,000 \\
Koefisien Lag FDGMM & 0,842 & 0,000 \\
Koefisien Lag Dynamic PLS Model & 0,989 & 0,000 \\
Uji Sargan & 33,961 & 0,985 \\
Uji Arellano-Bond $\left(\mathrm{m}_{1}\right)$ & $-4,319$ & 0,000 \\
Uji Arellano-Bond $\left(\mathrm{m}_{2}\right)$ & $-0,794$ & 0,427 \\
\hline
\end{tabular}

Sumber: RStudio (diolah)

Pengujian spesifikasi model menggunakan Uji Sargan untuk melihat validitas instrumen peubah yang digunakan. Hasil Uji Sargan pada Tabel 2 menunjukkan $p$-value sebesar 0,985 > 0,05. Artinya, tidak terdapat korelasi antar residual dan over identifying restrictions atau peubah instrumen yang digunakan lebih dari jumlah parameter yang diduga. Sehingga dapat dikatakan peubah instrumen yang digunakan valid. Uji spesifikasi model terakhir untuk melihat kekonsistenan model yang dibuat dengan Uji Arellano-Bond. Hasil Uji Arellano-Bond $\left(\mathrm{m}_{2}\right)$ pada Tabel 2 menunjukkan p-value sebesar 0,427 >0,05. Artinya, metode panel dinamis dengan pendugaan FDGMM Arellano-Bond telah memenuhi kriteria model terbaik.

Model data panel dinamis digunakan untuk mengetahui peubah bebas yang berpengaruh terhadap peubah tak bebas (NTN) baik dalam jangka panjang maupun jangka pendek. Selain itu, model data panel dinamis dapat digunakan untuk mengetahui kecepatan penyesuaian konvergensi dari NTN provinsi di Indonesia menuju suatu nilai tertentu, hingga tidak ada kesenjangan nilai NTN antar provinsi. Model yang digunakan adalah model double log dimana koefisien dari peubah bebas juga merupakan elastisitas dari setiap peubah bebas tersebut (Juanda, 2009). Penggunaan logaritma natural dalam melakukan pemodelan bertujuan untuk mengatasi hubungan yang nonlinier antara peubah tak bebas dan peubah bebas serta mengatasi ketidaknormalan sebaran data (Benoit, 2011). Model empiris dalam penelitian ini adalah:

$$
\ln \widehat{N T N}_{l t}=1,1838+0,842 \ln N T N_{i t-1}-0,1020 \ln I K R T_{i t}+0,001 \ln E K S_{i t}+0,001 \operatorname{lnCOV} i t
$$

Tabel 3. Signifikansi peubah dan elastisitas jangka pendek dan jangka panjang

\begin{tabular}{ccccc}
\hline \multirow{2}{*}{ Prediktor } & \multicolumn{2}{c}{ Jangka Pendek } & \multicolumn{2}{c}{ Jangka Panjang } \\
\cline { 2 - 5 } & Koefisien & $p$-value & Koefisien & $p$-value \\
\hline $\operatorname{lnIKRT}$ & $-0,1020$ & 0,442 & $-0,644$ & 0,526 \\
$\operatorname{lnEKS}_{\text {it }}$ & $0,0010^{*}$ & 0,000 & 0,006 & 0,068 \\
$\operatorname{lnCOV}_{\text {it }}$ & $0,0010^{*}$ & 0,000 & $0,009^{*}$ & 0,039 \\
\hline
\end{tabular}

*) signifikan pada taraf nyata 0,05

Sumber: RStudio (diolah)

Berdasarkan Tabel 3, hasil penelitian ini menunjukkan pada masa pandemi Covid-19, nilai ekspor perikanan tangkap berpengaruh positif terhadap NTN dalam jangka pendek. Artinya, peningkatan ekspor perikanan tangkap akan meningkatkan daya beli nelayan. Koefisien elastisitas nilai ekspor perikanan tangkap sebesar 0,0010 menunjukkan setiap peningkatan 10 persen ekspor perikanan tangkap di suatu provinsi, maka akan meningkatkan NTN sebesar 1 persen. Sedangkan dalam jangka panjang nilai ekspor perikanan tangkap tidak signifikan berpengaruh terhadap NTN. Hal ini sejalan dengan penelitian yang dilakukan oleh Ratnasari dan Rijanta (2020) menyatakan bahwa tidak terdapat hubungan yang signifikan antara nilai ekspor pertanian dengan dua indikator kesejahteraan petani (NTP dan NTUP). Hal ini juga sesuai dengan hasil penelitian Akbar (2020) menyatakan bahwa nilai ekspor berpengaruh positif terhadap NTP subsektor tanaman pangan. Selain itu, berdasarkan penelitian yang dilakukan oleh Setiawan (2016) menyatakan bahwa ekspor perikanan tangkap dipengaruhi harga pasar. Permintaan produk Sektor Kelautan dan Perikanan pada masa akan datang ditentukan oleh jumlah konsumen, pola konsumsi, tingkat pendapatan, dan harga di pasar (Rizal et al., 2018). Hal ini menunjukkan dalam jangka panjang pengaruh ekspor perikanan tangkap terhadap NTN bergantung pada mekanisme pasar.

Jumlah penambahan kasus aktif Covid-19 menunjukkan pengaruh positif terhadap NTN, baik dalam jangka pendek maupun jangka panjang. Semakin bertambah jumlah kasus aktif Covid-19 maka NTN akan naik. Koefisien elastisitas peubah penambahan jumlah kasus aktif Covid-19 menunjukkan bahwa setiap peningkatan 10 persen kasus aktif covid-19 di suatu provinsi, maka akan meningkatkan NTN dalam jangka pendek sebesar 1 persen dan 9 persen pada jangka panjang. Seiring dengan penambahan jumlah kasus aktif 
Covid-19, pemerintah memberikan bantuan sosial berupa bantuan langsung tunai (BLT) dan paket sembako (Indrawati, 2020). Hal ini berimbas pada kestabilan harga kebutuhan pangan di pasar. Selain itu, pemerintah juga menerapkan Pembatasan Sosial Berskala Besar (PSBB) sehingga banyak nelayan yang berhenti melaut (Bromo, 2020). Hal ini menyebabkan terganggunya pasokan ikan di pasar, sehingga harga ikan di tingkat nelayan naik (Mankiw, 2007).

IKRT menggambarkan perkembangan harga kebutuhan barang dan jasa yang dikonsumsi rumah tangga tidak signifikan berpengaruh terhadap NTN baik jangka pendek maupun dalam jangka panjang. Hal ini sejalan dengan penelitian yang dilakukan oleh Misnatun (2020) menyatakan bahwa konsumsi rumah tangga tidak berpengaruh secara signifikan terhadap petani penggarap kopi dalam kesejahteraan di Kabupaten Tanjung Jabung Barat, Jambi.

Speed of convergence menunjukkan kecepatan konvergensi daya beli nelayan (NTN) antar provinsi menuju ke nilai NTN tertentu (steady state). Nilai kecepatan konvergensi sebesar 17,21 persen per bulan artinya setiap bulan terjadi pengurangan kesenjangan daya beli nelayan (NTN) antar provinsi sebesar 17,21 persen dengan asumsi tidak ada guncangan dari luar yang berarti. Waktu yang diperlukan untuk menutup setengah kesenjangan (half time convergence) daya beli nelayan yaitu 4 bulan.

\section{KESIMPULAN}

Pada masa pandemi Covid-19 periode Januari-Desember 2020, nilai ekspor perikanan tangkap dan penambahan jumlah kasus aktif Covid-19 berpengaruh terhadap daya beli nelayan (NTN). Kesenjangan daya beli nelayan antar provinsi berkurang sebesar 17,21 persen per bulan. Kesenjangan NTN berkurang setengahnya dari kondisi awal (half time convergence) dapat dicapai dalam waktu 4 bulan, dengan asumsi tidak ada guncangan dari luar.

Berdasarkan hasil penelitian ini, maka untuk mendukung percepatan pemulihan ekonomi nelayan di masa pandemi, pemerintah sebaiknya memberikan bantuan secara tunai maupun non tunai untuk menjaga tingkat konsumsi nelayan dan memberikan pelatihan mengenai cara penanganan ikan yang baik untuk meningkatkan kualitas ekspor. Selain itu, penelitian ini tidak melakukan analisis pengaruh spasial dan penambahan peubah iklim terhadap NTN di Indonesia. Sehingga perlu dilakukan penelitian lanjutan dengan menambahkan unsur spasial/matrik bobot lokasi dan peubah iklim.

\section{DAFTAR PUSTAKA}

Akbar, T. (2020). Faktor-faktor yang Mempengaruhi Nilai Tukar Petani Tanaman Pangan Provinsi Kalimantan Selatan. Tesis Universitas Lambung Mangkurat. Banjarbaru.

Anna, Z. (2019). Pemanfaatan Model Bio-Ekonomi Dalam Pengelolaan Sumber Daya Perikanan yang Berkelanjutan. Universitas Padjadjaran. Bandung.

Arellano, M., dan Bond, S. (1991). Some Tests of Specification for Panel Data: Monte Carlo Evidence and an Application to Employment Equations. Oxford Journals, 277-297.

Baltagi, B. H. (2008). Econometrics. Springer Berlin Heidelberg.

Benoit, K. (2011). Linear Regression Models with Logarithmic Transformations. Kenbenoit.net. Cited in https://kenbenoit.net/assets/courses/ME104/logmodels2.pdf. [21 Juli 2021]

BPS. (2021). Data Laju Pertumbuhan Produk Domestik Bruto (PDB) Tahun 2020. Badan Pusat Statistik RI.

BPS. (2021). Statistik Indonesia. Badan Pusat Statistik RI.

BPS. (2021). Statistik Nilai Tukar Petani 2020. Jakarta: Badan Pusat Statistik RI.

BPS. (2021). Statistik Perdagangan Luar Negeri Indonesia Ekspor Menurut Kode ISIC, 2019-2020. Badan Pusat Statistik RI.

Bromo, R. (2020). Cuaca Buruk, Harga Ikan Nelayan di Pasuruan Anjlok. Radar Bromo. Cited in https://radarbromo.jawapos.com/utama/07/08/2020/cuaca-buruk-harga-ikan-nelayan-di-pasuruananjlok/. [21 Juli 2021]

Darwis, V., Maulana, M., dan Rachmawati, R. R. (2020). Dampak Pandemi Covid-19 terhadap Nilai Tukar Petani dan Nilai Tukar Usaha Pertanian. Dampak Pandemi COVID-19: Perspektif Adaptasi dan Resiliensi Sosial ekonomi Pertanian, 83-103.

Indrawati. (2020, 11 5). Produksi Perikanan Naik Selama Pandemi, Tapi Kepiting Rajungan Tidak Terjual. Mongabay. Cited in https://www.mongabay.co.id/2020/11/05/produksi-perikanan-naik-selama-pandemitapi-kepiting-rajungan-tidak-terjual/. [21 Juli 2021]

Juanda, B. (2009). Ekonometrika: Pemodelan dan Pendugaan. IPB Press. 
Kholis, M. N., Fraternesi, dan Wahidin, L. O. (2020). Prediksi Dampak COVID-19 Terhadap Pendapatan Nelayan Jaring Insang di Kota Bengkulu. ALBACORE Jurnal Penelitian Perikanan Laut, 1-11.

KPCPEN. (2021). Covid-19 Indonesia Dataset 2020. Kaggle Hendratno. Cited in https://www.kaggle.com/hendratno/covid19-indonesia/version/81. [21 Juli 2021]

Mankiw, G. (2007). Macroeconomics. Worth Publishers.

Misnatun. (2020). Pengaruh Pendapatan dan Konsumsi Rumah Tangga Terhadap Kesejahteraan Petani Penggarap Kopi. Tesis UIN Sulthan Thaha Saifuddin. Jambi. 98 hlm.

Rachmat, M. (2013). Nilai Tukar Petani: Konsep, Pengukuran dan Relevansinya Sebagai indikator Kesejahteraan Petani. Forum Penelitian Agro Ekonomi, 1-11.

Ramadhanu, R. (2021). Analisis Faktor-Faktor Yang Mempengaruhi Nilai Tukar Petani di Provinsi Sumatera utara. Tesis Universitas Sumatera Utara. Medan. $75 \mathrm{hlm}$.

Ratnasari, E., dan Rijanta, R. (2020). Dimensi Spasial Hubungan Antara Ekspor Pertanian dengan Nilai Tukar Petani dan Nilai Tukar Usaha Pertanian Sebagai Indikator Kesejahteraan Petani di Indonesia. Universitas Gajah Mada. Yogyakarta.

Rizal, A., Iskandar, Herawati, H., dan Dewanti, L. P. (2018). Potret dan Review Strategi Pembangunan Perikanan dan Kelautan Indonesia. Unpad Press.

Sariagri. (2020). Aktivitas Perikanan di Indonesia Didominasi Nelayan Kecil. Sariagri.id. Cited in https://perikanan.sariagri.id/59981/aktivitas-perikanan-di-indonesia-didominasi-nelayan-kecil. [21 Juli 2021]

Setiawan, A. (2016). Pengaruh Nilai Tukar Pertumbuhan ekonomi, Harga Ekspor, Terhadap Ekspor Ikan Tuna Indonesia Tahun 2002-2014 (Ekspor Indonesia Terhadap jepang). Tesis UIN Syarif Hidayatullah. Jakarta. $108 \mathrm{hlm}$.

UNICEF, UNDP, Prospera, dan The SMERU, R. I. (2021). Ringkasan Eksekutif: Dampak Sosial Ekonomi COVID-19 Terhadap Rumah Tangga dan Rekomendasi Kebijakan Strategis untuk Indonesia. Smeru.or.id. Cited in https://smeru.or.id/sites/default/files/publication/es_covundp_id.pdf. [21 Juli 2021]

Yuniasih, A. F., Firdaus, M., dan Fahmi, I. (2013). Disparitas, Konvergensi, dan Determinan Produktivitas Tenaga Kerja Regional di Indonesia. Jurnal Ekonomi dan Pembangunan Indonesia, 63-81. 